\title{
Using Primary Care to Address Violence against Women in Intimate Partner Relationships: Professional Training Needs
}

\author{
Aida Torralbas-Fernández MS and Marybexy Calcerrada-Gutiérrez MS
}

\begin{abstract}
Unified, prevention- and community-oriented, Cuba's National Health System is well positioned to address social problems such as gender violence against women. It is sometimes taken for granted that family doctors, family nurses and psychologists in the health system should be able to deal with such cases. However, some studies among these professionals have revealed misconceptions about intimate partner violence, an insufficient understanding of its causes, and greater tolerance of psychological violence than of physical and sexual violence. Cuba needs to train family doctors and clinical psychologists who are knowledgeable about the subject so that they can take part in the development and implementation of intersectoral education and prevention policies and programs, provide assistance to women who have been victims of violence, and work together with community members to create support networks that serve as monitoring mechanisms. Primary care is the ideal setting for raising awareness of the need for greater intersectoral action to systematically address violence against women.
\end{abstract}

KEYWORDS Professional training, doctors, clinical psychologists, gender, spousal abuse, domestic violence, family violence, family relationships, Cuba

\section{INTRODUCTION}

Gender violence is the result of socially determined asymmetrical power relationships between men and women. The UN defines violence against women as "any act of gender-based violence that results in, or is likely to result in physical, sexual or mental harm or suffering to women, including threats of such acts, coercion or arbitrary deprivation of liberty, whether occurring in public or private life."[1] UN Sustainable Development Goal 5 explicitly calls for gender equality and empowerment of women and girls, and advocates for systematic integration of a gender perspective into the development agenda.[2]

Cultural and legal studies have revealed that historically, women as wives have lived under the "protection" of their spouses or partners in a patriarchal context. Expressions of subordination persist globally, including subtle forms of domination that have contributed to certain types of abuse and mistreatment going unnoticed.[3]

A number of international fora and documents have affirmed the need to denounce and eliminate conditions for, and manifestations of, violence against women.[4-6] WHO's World Report on Violence and Health considered domestic violence against women a social problem, and called attention to its multiple expressions and their negative effects on the welfare of various population groups. It also pointed out that women tend to be the most frequent victims of domestic violence, reporting that 48 surveys from around the world found that $10 \%-69 \%$ of women had experienced intimate partner violence at least once.[7] The feminist movement has condemned domestic violence as a worldwide phenomenon and succeeded in placing it on the international agenda as a priority for achieving a more equitable world.[8] The problem everywhere must be addressed with an interinstitutional strategy not confined to the health sector.[9]

As a cultural phenomenon, the nuances of violence against women vary in different parts of the world, depending on social and historical contexts.[10] Cuba is not exempt, with a range of expressions, particularly psychological or emotional violence, most frequently perpetrated against wives or female partners. While governmental and nongovernmental organizations as well as Cuban media have addressed the issue,[11] there is still much to be done.

The main objective of this paper, which draws on research in Holguín, capital of the northeastern Cuban province of the same name, is to bring attention to primary care practitioners' current limitations in understanding and addressing violence against women in heterosexual couples.

\section{HEALTH PROFESSIONALS AND VOLENCE AGAINST WOMEN}

Violence is a community health problem and requires a public health approach in the broadest sense. A gender perspective provides the basis from which to detect and characterize the problem and for strategic planning to address it, which requires recognition of its historical and social determinants.[12] Scott points out that the category of gender conceptually goes beyond social constructs that revolve around supposedly proper roles for women and men, and underscores power relations implicit in them.[13] Bearing in mind that human health is determined by social and environmental factors marked by culture, gender roles play out in ways that put men and women in different and specific positions concerning risk to and protection of health. A gender perspective in health should take into account not only differential exposure to risk, but also differentially distributed power for dealing with such risks.[14] This broader perspective highlights the role that health workers can play in preventing domestic violence against women and caring for its victims.

In addition to treatment, health professionals can provide legal, social and psychological protection to victims, which could in turn help free them from abusive conditions or make them more aware of them, as a starting point for the decisions they make. Health workers can form multidisciplinary teams with legal professionals, educators, sociologists and social workers, and in coordination with the legal sector, identify and report cases of violence.

Health professionals can also provide guidance on design of communications materials with health messages in the media, to stimulate awareness in identifying manifestations of violence and, above all, to prevent them. They can also contribute to expanding confidential, freely accessible counseling services. 
Domestic violence against women in Cuba As early as the first half of the 20th century, Cuban women enjoyed a relatively privileged status, with examples including the right to vote and legal divorce.[15] After 1959, there were new opportunities for women to achieve personal autonomy and social equality with men, including access to abortion, free and universal medical care, equal pay for equal work, and legal recognition of domestic unions outside of marriage (the latter particularly important in cases of separation and child custody or support).[15] Currently, Cuban women are notable for taking leading roles in professional and political life: for example, Cuba has one of the highest proportions of female parliamentary representation in Latin America,[15] and $70.6 \%$ of health workers are women, including a majority of professionals in the sector.[16]

However, economic independence, educational gender parity and equality of opportunities are not enough to eradicate gender inequality. Despite socioeconomic and cultural gains that single out Cuba among many other countries in Americas and the world, pervading sociopsychological factors mean Cuban women are not exempt from risk of violence in their intimate relationships. [17] Previous research among women in a health center in Havana reported that $70.4 \%$ of them had been victims of some kind of violence. Although psychological violence prevailed, acts of physical violence were also reported in more than $50 \%$ of the population studied.[18]

Drawing from personal experience in projects of multidisciplinary counseling services staffed by volunteers and sponsored by the Federation of Cuban Women, we know from direct observation that shelters for female victims of violence or specialized services for dealing with intimate partner violence are still not universally available in the country. For that reason, Cuba's 2013 report to the Committee for Eradication of Discrimination against Women suggests the creation of such specialized services with a multidisciplinary approach to cope with the problem and improve support for victims of violence.[19]

In the absence of specific legislation or a governmental institution specialized in care and support for victims of gender violence, women most frequently turn to SNS institutions for help, but there is evidence that SNS professionals could be more effective. Forms of violence involving limits on autonomy, role overload, jealousy, and other such subtle manifestations, are not typically understood as being within the purview of health professionals' competence. Rather, these tend to be seen as a "natural" expression of Cuban culture and Cubans' character. Even family doctors and psychologists often tolerate them to an extent, due perhaps to the fact that their professional training does not prepare them to properly deal with the issue, as shown in our research in Holguín. $[20,21]$

Potential role for primary health care professionals The first level in the SNS is primary care, which focuses on health promotion, disease prevention and health care in community settings.[22] Primary care in Cuba has two basic components: family doctorand-nurse offices (CMF) and polyclinics. The former provide first-line care for up to 1500 individuals or about 350 families in their own neighborhood, and the latter (each of which supervises a number of CMFs) are multispecialty clinics (pediatrics, OBGYN, internal medicine, psychiatry and psychology, etc.) that also provide laboratory and rehabilitation services. Family doctors refer patients to the polyclinic,[23] and since the 1990s, both family physicians and polyclinics can refer them to community mental health centers.[24]

Primary care provides many opportunities for professionals to address domestic violence against women. The neighborhoodbased family doctors and nurses interact mostly with women, who, in addition to seeking medical services for themselves, in their role as caregivers normally accompany children and the older adults to consultations. Also, during regular house calls, family doctors or nurses can readily identify dysfunctional dynamics at home through direct observation and inquiry, as well as from observations by neighbors. As informal leaders in the community, in cases of violence they can interact with local organizations and residents to constitute support networks.

As we envision it, addressing violence at this level would involve multisector work focused on recognition and prevention of sociocultural factors inherent in relationships marked by violence. This would begin by involving not only the family doctor-and-nurse offices and polyclinics, but also the mental health centers, which could offer violence prevention and victim support programs, as well as training to help primary health care workers recognize and treat girls and women of all ages who have experienced any type of violence, particularly domestic.

Such training is key at all career moments, since although primary care physicians, nurses and psychologists are well placed to prevent, detect, treat and refer cases of domestic violence against women, their effectiveness is hampered by insufficient professional preparation. In our view, their performance is also constrained by patriarchal socialization. As a result, we believe that professionals refrain from intervening in domestic violence involving their patients because of a belief that it is a private matter, or that women are weak and self-effacing and thus contribute to perpetuating their condition as victims. Our research in Holguin indicates that it is not uncommon to hear expressions such as: intimate partner violence is caused by alcohol or emotional disorders in men; jealousy is a sign of love; and obedience means respect.[20,21]

Supporting evidence from family doctors A survey of all 19 family doctors in a primary care health area (consisting of a polyclinic and its reporting CMFs) in the city of Holguín revealed prevalent gender stereotypes characteristic of patriarchal culture. Over $70 \%$ of respondents stated that the causes of violence against women in intimate-partner relationships are primarily communication problems within the couple, that the majority of abusive husbands commit abuse because of their dominant and violent natures, and that economically independent women who tolerate abuse do so because they are especially weak and insecure.[20]

It has been observed that doctors tend to overlook the abuse of power at the root of violent behavior and communication problems. They focus on the observable signs and not on the underlying sociocultural factors that produce gender-related inequity. It is not uncommon that such expressions of violence are confined to the partner relationships, and are less frequent in other contexts where such power disparities are absent or not as marked.[17]

Casting the analysis of gender domestic violence only in terms of women's economic independence or equality of opportunities 
ignores insecurity, fears, gradual corrosion of self-esteem, learned helplessness and other psychological factors that also play an important role. Passiveness of the victim's family can also provide unconscious support to the perpetuation of psychological gender violence-more often than not without physical expressionswhich traditionally is more socially and culturally tolerated.[17]

Supporting evidence from clinical psychologists A survey of clinical psychologists in Holguín used the same instrument as the research with family doctors (Table 1) and yielded a similar pattern of answers. $[20,21]$ The psychology curriculum insufficiently addresses the issue of violence against women, its link to power and the issue of gender perspective. Topics related to clinical specialization are centered in psychopathology, psychotherapy, psychological counseling and others, in which gender violence is not specifically treated. Intimate violence against women is partly included in some subjects within social psychology, but with no deep analysis from a gender perspective.[25] A possible reason is the historical and cultural focus of teaching and practice of psychology in Cuba, to the detriment of attention to the differential socialization of men and women and its impact on personality.[26]

Table 1: Questionnaire content on myths about gender violence against women[21,22]

Please indicate true $(T)$, false $(F)$ or no opinion (NR) for each of the statements below. Add comments if you wish.

An economically independent woman who tolerates domestic violence does so because she is especially weak and insecure. Women's educational level, age, social class, occupation and economic status do not prevent them from experiencing abuse in intimate relationships.

Generally, when a man repeatedly mistreats and humiliates his partner, it is because he has emotional problems that make him lose control.

When a woman belongs to an intellectual family with academic achievement and good standard of living, she is unlikely to be abused by her partner.

Sometimes women behave in such a way as to justify men's abuse.

Violence against women in intimate relationships is caused mainly by couples' communication problems.

Most violent acts are committed by strangers.

Most men who abuse their wives do it because they are dominant and violent by nature.

Intimate partner violence is a private matter that should be resolved between the partners themselves.

A shift toward an approach with more emphasis on the sociocultural origin of the human psyche could provide a framework conducive to mainstreaming gender analysis in the various subjects taught to psychology students.

The above-mentioned study included 21 clinical psychologists-at the time, the entire SNS psychology staff in the city of Holguínand found that they were more tolerant of psychological violence than physical or sexual abuse.[21] The most-tolerated expressions of psychological violence were those associated with gender stereotypes, such as those related to jealousy and to husbands' control over family finances and their partners' relationships and activities outside the home. A plausible inference is that, although the psychology curriculum in Cuba has the declared intent of training graduates in the general principles of social determination,[25] the roles of tradition, power relations, social disadvantage, dominant cultural discourse and the organization of institutions themselves do not receive due emphasis.

The same study found that more than $60 \%$ of psychotherapists believed spousal abuse to be frequently due to emotional disorders impairing men's self-control, and a similar proportion considered intimate partner violence to be due to communication problems.[21]

Addressing the problem The results of these studies in Holguín suggest that even professionals such as family doctors and clinical psychologists may misunderstand violence against women in intimate partner relationships. This is a matter of some concern, because there are no a priori reasons to believe that the Holguín findings cannot be extrapolated to other regions of Cuba, since professional curricula are standardized nationwide. How violence and its causes are understood and interpreted can either favor prevention and proper management of the problem or hide and perpetuate it. According to Femenías,[27] when social structures reproduce a patriarchal ideology even in democratic and nonexclusionary societies, violence against women in intimate partner relationships might be concealed to the point of promoting omission and silence among women themselves.

The proper approach to the problem cannot be the exclusive concern of a single sector or social institution. Various social sectors need to devise strategies that respond organically to cultural change embodied in specific practices. Family doctors, nurses and clinical psychologists-to different degrees and if properly instructed and trained — can provide psychological support to women who are victims of violence, and play a crucial role in helping women fully understand their situation, assign responsibility where it belongs, and free themselves from abusive relationships. $A$ first step toward this goal would be collection and dissemination of reliable information on the magnitude of the issues.

All medical graduates, including nurses and psychologists, should take courses that address gender issues in general and help them understand the social causes of differences between men and women and how these differences impact gender relations and gender inequalities. This could lead to better understanding and greater awareness of the problem of violence against women in intimate partner relationships, which should be addressed in depth in the training of family physicians. The clinical psychology curriculum should address understanding behavior from a gender perspective, and psychologists' academic training should enhance cultural education with a historical perspective, to develop professional skills for understanding the historical, social and cultural bases of behavior, as well as the distribution of authority and ways of exercising it.

Because the phenomenon of domestic violence against women is complex, there is a need for specialized multidisciplinary services that involve physicians, psychologists, nurses, legal professionals, police officers and social workers trained in gender violence, to cope with specific cases of violence against women. Such cross-sector services would offer emotional support and contribute to education about gender equity. Intersectoral participation with a gender perspective encourages implementation of comprehensive social policies to reduce vulnerability. This proposal is consistent with the ideas of Cuban 
gender scholars such as Artiles in the health sector[28] and Proveyer in sociology.[11] Specific legal provisos concerning gender violence in all its manifestations in Cuba are required to provide a framework for more concrete actions to combat it.

\section{MOVNG FORWARD}

Cuba's SNS has the potential to play a leading role in preventing intimate partner violence against women and helping its victims. However, health professionals' lack of awareness of gender issues and the cultural roots of violence against women and its impacts could contribute to maintaining or even reinforcing violent relationships. The Holguín study results suggest that professional curricula in medicine and psychology need to address issues of gender and violence against women. The topic should be included in training and frequent refreshers during undergraduate, graduate and postgraduate education for health professionals, especially those working in primary care.

Although the problem is not the exclusive purview of the SNS, psychologists and family physicians need training that prepares them to provide systematic support to victims, including coordinated actions with other members of the community to generate support networks and monitoring mechanisms. As with many other problems that are of direct-albeit not exclusiveconcern to the health sector, prevention through education is a key component of any strategy aimed at systemically addressing violence against women as a social problem. Raising health professionals' awareness is a necessary prerequisite. -1 -

\section{REFERENCES}

1. United Nations. The United Nations Declaration on the Elimination of Violence against Women 1993, General Assembly 48/104, 85th plenary meeting, 20 December 1993 [Internet]. New York: United Nations; 1993 Dec 20 [cited 2015 Feb 21]. Available from: http://www.un.org/documents/ga/res/48/ a48r104.htm

2. United Nations [Internet]. New York: United Nations; c2016. Sustainable Development Knowledge Platform. Transformar nuestro mundo: la Agenda 2030 para el desarrollo sostenible [Transforming our world: the 2030 agenda for sustainable development]; 2015 Sep 18 [cited 2015 Dec 5]. 40 p. Available from: https://sustainabledevelopment. un.org/post2015/transformingourworld. Spanish.

3. Lorente Acosta M. Consecuencias y características de las agresiones a las mujeres. Aspectos médicos-forenses. In: Foro Andaluz contra la violencia de género. Sevilla: Instituto Andaluz de la Mujer; 2000. p. 55-66. Spanish

4. Republic of Panama National Government. Protocolo Facultativo de la Convención sobre la eliminación de todas las formas de discriminación contra la mujer [Internet]. Panama City: United Nations; 2010 Nov [cited 2015 Nov 20]. 55 p. Available from: http://www.unicef.org/panama/spanish/ MujeresCo_web.pdf. Spanish.

5. United Nations Population Fund [Internet]. New York: United Nations Population Fund; c2016. Conferencia Internacional sobre Población y Desarrollo; 2014 Sep [cited 2016 Feb 22]. Available from: http://www.unfpa.org/es/conferencia-interna cional-sobre-la-poblaci\%C3\%B3n-y-el-desarrollo. Spanish.

6. United Nations. Plataforma de Acción de Beijing [Internet]. New York: United Nations; 1995 Sep [cited 2016 Feb 22]. p. 111-5. Available from: http://www .un.org/womenwatch/daw/beijing/pdf/BDPfA $\% 20 S$ .pdf. Spanish.

7. World Health Organization. Informe mundial sobre la salud y la violencia. Resumen [Internet]. Washington, D.C.: World Health Organization; Pan American Health Organization; 2002 [cited 2015 Nov 25]. 62 p. Available from: http://www.who.int/ violence_injury_prevention/violence/world_report/ en/summary_es.pdf. Spanish.

8. García Moreno C. La actuación de los organismos internacionales contra la violencia hacia la mujer: Organización Mundial de la Salud. In: Foro Andaluz contra la violencia de género. Sevilla: Instituto Andaluz de la Mujer; 2000. p. 16. Spanish.

9. Gómez Valverde L. La violencia en el ámbito privado, un asunto público. In: Foro Andaluz contra la violencia de género. Sevilla: Instituto Andaluz de la Mujer; 2000. p. 45-54. Spanish.

10. Femenías ML. Los ríos subterráneos. Violencias cotidianas (en la vida de las mujeres). Rosario: Prohistoria Ediciones; 2013. p. 15-32.
11. Proveyer C. Violencia de género. Aproximaciones desde la realidad cubana. Rev Sexología y Sociedad [Internet]. 2014 [cited 2015 Nov 25];20(1):317. Available from: http://revsexologiaysociedad .sld.cu/index.php/sexologiaysociedad/rt/printer Friendly/465/507. Spanish.

12. Más S. Ada Alfonso: Hace falta una norma que regule la atención integral a la violencia. SEMlac Cuba [Internet]. 2014 Dec 10 [cited 2015 Dec 15]; [about 2 screens]. Available from: http://www .redsemlac-cuba.net/violencia/ada-alfonso-hace -falta-una-norma-que-regule-la-atenci\%C3\%B3n -integral-a-la-violencia.html. Spanish.

13. Scott J. El género: Una categoría útil para el análisis histórico. In: Bourque SC, Butler JP, Lamas $M$, editors. El género: la construcción cultural de la diferencia sexual. Mexico City: PUEG; 1996. p. 265-302. Spanish.

14. Castañeda I. Reflexiones teóricas sobre las diferencias en salud atribuibles al género. Rev $\mathrm{Cu}$ bana Salud Pública [Internet]. 2007 [cited 2015 Nov 25];33(2). Available from: http://scielo.sld.cu/pdf/ rcsp/v33n2/spu11207.pdf. Spanish.

15. Vasallo Barrueta N. Ecos del pasado, voces del presente. Un acercamiento a ideas y objetivos feministas de las cubanas. In: Ecos distantes, voces cercanas, miradas feministas. Havana: Editorial de la Mujer; 2012. p. 67-81. Spanish.

16. Ministry of Public Health (CU). Anuario Estadístico de Salud 2015 [Internet]. Havana: Ministry of Public Health (CU); 2016 [cited 2016 Apr 15]. p. 18. Available from: https://www.researchgate.net/ publication/301226389_Anuario_estadistico_de Salud 2015. Spanish.

17. Vega S. Violencia familiar: los maltratos inconfesables en las relaciones. In: Psicología Social II. Vol. 3. Havana: Editorial Félix Varela; 2005. p. 50-65. Spanish.

18. Gil O. Situación de la violencia doméstica en la mujer, en la población del policlínico "Julio Antonio Mella”. Rev Cubana Salud Pública [Internet]. 2011 [cited 2016 Aug 22]; 27(4). Available from: http:// scielo.sld.cu/scielo.php?script=sci_arttext\&pid =S0864-21252011000400007. Spanish.

19. United Nations [Internet]. New York: United Nations; c2016. Convención sobre la eliminación de todas las formas de discriminación contra la mujer. Comité para la Eliminación de la Discriminación contra la mujer. $55^{\circ}$ período de sesiones. Lista de cuestiones y preguntas en relación con el examen de los informes periódicos: Cuba. Respuestas de Cuba a la lista de cuestiones que deben abordarse al examinar los informes periódicos séptimo y octavo combinados (CEDAW/C/ CUB/7-8)*; 2013 [cited 2016 Aug 20]. 8 p. Available from: http://www2.ohchr.org/English/bodies/ cedaw/docs/CEDAW.C.CUB.Q.7-8.Add.1_sp.pdf. Spanish.
20. Cruz Vilanova R, Torralbas Fernández A. El médico de la familia y la violencia contra la mujer. In: Arias Guevara MA, Torralbas Fernández A, Pupo Vega A, editors. Rompiendo silencios. Lecturas sobre mujeres, géneros y desarrollo humano. Havana: Editorial de la Mujer; 2013. p. 73-88. Spanish.

21. Torralbas A. El psicólogo clínico y la violencia de género contra la mujer [thesis]. [Havana]: University of Havana School of Psychology; 2010. Spanish.

22. Sánchez Santos L, Amaro Cano MC. La salud pública en Cuba. In: Álvarez Sintes R, editor. Temas de Medicina General Integral. Havana: Editorial Ciencias Médicas; 2001. p.1-6. Spanish.

23. Domínguez-Alonso E, Zacca E. Sistema de salud de Cuba. Salud Púb Méx. 2011;53(Suppl. 2):S16876. Spanish.

24. Gorry C. Community mental health services in Cuba. MEDICC Rev. 2013 Oct;15(4):4.

25. Plan de estudio Carrera de Psicología. Comisión de Carrera. Havana: University of Havana; 2012. Spanish.

26. Vasallo Barrueta N, editor. La subjetivación del género desde una lectura a Vigotski y Leontiev. In: Ecos distantes, voces cercanas. Havana: Editorial de la Mujer; 2012. p. 95-105. Spanish.

27. Femenías ML. Violencias cotidianas (en la vida de las mujeres). Rosario: Prohistoria Ediciones; 2013. p. 101-2. Spanish.

28. Artiles L. Incorporating a gender perspective into Cuba's health system: realities and challenges. MEDICC Rev. 2012 Apr;14(2):39-42.

\section{THE AUTHORS}

Aida Torralbas-Fernández (Corresponding author: atorralbas@fh.uho.edu.cu), psychologist with master's degrees in clinical psychology and gender studies. Associate professor, Psychology Department, University of Holguín, Cuba.

Marybexy Calcerrada-Gutiérrez, psychologist with a master's degree in gender studies. Assistant professor, Psychology Department, University of Holguín, Cuba.

Submitted: November 30, 2015

Approved for publication: May 27, 2016

Disclosures: None 